\title{
Political economists are neither selfish nor indoctrinated
}

Working Paper

Author(s):

Frey, Bruno S.; Meier, Stephan

Publication date:

2000

Permanent link:

https://doi.org/10.3929/ethz-a-004373695

Rights / license:

In Copyright - Non-Commercial Use Permitted

Originally published in:

Working paper / Institute for Empirical Research in Economics 69 


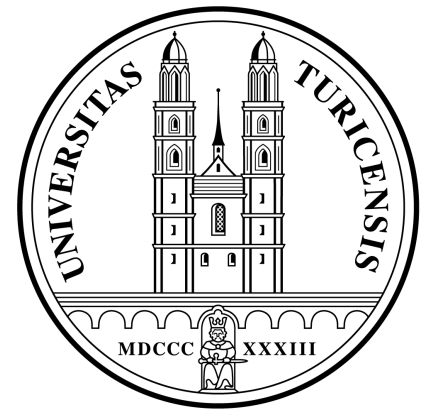

Institute for Empirical Research in Economics

University of Zurich

Working Paper Series

ISSN 1424-0459

Working Paper No. 69

\section{Political Economists are Neither Selfish nor Indoctrinated}

Bruno S. Frey and Stephan Meier

December 2000 


\title{
POLITICAL ECONOMISTS ARE NEITHER SELFISH NOR INDOCTRINATED
}

\author{
Bruno S. Frey \\ Stephan Meier* \\ (University of Zurich) \\ Preliminary version \\ (December, 3 2000)
}

\begin{abstract}
Most professional economists believe that economist in general are more selfish than other persons and that this greater selfishness is due to economic education. In this paper we offer empirical evidence against this widely held belief. Using a unique data set about giving behaviour to two social funds at the University of Zurich, it is shown that economic training does not make people act more selfish. However, the 'natural experiment' supports the hypothesis that the different behaviour of economist can be explained by a selection effect.
\end{abstract}

JEL classification: A13, A20, H41

Keywords: Economists, Public Good, Giving Behaviour

\footnotetext{
${ }^{*}$ Bruno S. Frey is professor, and Stephan Meier is research assistant, of economics at the University of Zurich. Address: Institute for Empirical Economic Research, University of Zurich, Blümlisalpstrasse 10, 8006 Zurich, Tel.: 0041-1-634 37 28, Fax: 0041-1-634 49 07, E-mail: bsfrey@iew.unizh.ch, smeier@iew.unizh.ch. We thank ... for helpful remarks.
} 
Most professional economists, and probably most other scholars, seem to believe that the following statements are a fact beyond doubt:

(1) Economists are more selfish than other persons,

(2) Economists' higher selfishness is at least partly due to the economics education.

Frank, Gilovich and Regan $(1993,1996)$ thus seem to have convinced the academic community. Using Prisoner's Dilemma experiments they found that economics majors (at a particular American university) are more self-interested than non-majors, and that this is caused in part by their training in economics. They conclude that there is "... a heavy burden of proof on those who insist that economics training does not inhibit cooperation"(1996:192).

But the literature on the topic has reached much less uniform results than this statement as well as the view held among many scholars suggest. While Carter and Iron (1991:174) using an Ultimatum Game experiment find that "economists are born, not made", Yezer, Goldfarb and Poppen (1996:177) using a "lost letter" experiment even claim that economists are "... actually substantially more cooperative than ... their counterparts studying other subjects"1. These inconsistent conclusions are all based on experiments with students. An exception is Laband and Beil (1999) who look at how far the professional associations' income-based dues structures without enforcement mechanism are observed. For that purpose they undertake a survey of the members" "true" income and find that sociologists are more prepared to cheat than either economists or political scientists. But this study does not control for personality variables, and cannot discriminate between the so-called selection and indoctrination effect. Therefore "[t]he effect of training and/or self-selection on cooperation remains a wide-open problem" (Ledyard 1995: 161).

We are able to use a unique and extremely large data set (more than 57,000 observations) to study the behavior of economics students in a natural setting, to compare it with that of students of other disciplines, and to analyze whether a possible difference in behavior is due to the indoctrination in the economics training. We reach significantly different results from all the other studies:

(1) Political economists are not more selfish than the average of all other students, but students of business are much more selfish.

\footnotetext{
${ }^{1}$ Further studies unable to find an negative effect on cooperation of economics education are Marwell and Ames (1981), Frey, Pommerehne and Gygi (1993), Bohnet und Frey (1995), Seguino, Steven and Lutz (1996), Cadsby and Maynes (1998), Stanley and Tran (1998), and Frank and Schulz (2000).
} 
(2) The higher selfishness of business students is due to self-selection, not indoctrination.

(3) Students of the economic sciences (i.e. both political and business economists) are about as selfish as students of law but much less so than medical and veterinary students.

It follows that political economists can be more comfortable with their subject than most of them believe - it is in this respect not a dismal science. Professors of political economics cannot be faulted. But business schools should be fully aware that they attract particularly selfish students and should take that into account in their decisions. Our findings also serve to reject the often-heard claim ${ }^{2}$ that political economists create the type of selfish persons (the homo oeconomicus) they axiomatically assume in their theories.

Section I discusses the data and section II presents the analysis and results of our inquiry. Section III draws conclusions.

\section{The Data}

All students of the University of Zurich have to decide every semester if they want to contribute to two official social funds - additionally to the compulsory fee. On the official letter for renewing their registration the students are asked if they voluntarily want to give a specific amount (CHF 7.-, about US\$ 5) to a fund which gives cheap loans to needy students and/or a specific amount (CHF 5.-, about US\$ 3.30) to a fund supporting foreigners to study at the University of Zurich. Students also have the choice not to contribute to any fund at all. The students confirm their decision with their signatures. Our data refers to the decisions taken in the winter term 1998/99, the summer term 1999 and the winter term 1999/2000. The fact that every student of the University of Zurich has to decide every semester if he or she is willing to contribute to one or both of the social funds generates a large number of observations (the decisions of the three terms are pooled; $\mathrm{N}=57,510$ ). Problems of a selection bias of the subject-pool are minimal. The data enable to compare the effect of studying different disciplines ${ }^{3}$ on cooperative behavior and provides the opportunity to control for a possible effect of economics training.

\footnotetext{
${ }^{2}$ See Kelman (1987) and Ostrom (1998). The latter warns: "We are producing generations of cynical citizens with little trust in one another, much less in their government. Given the central role of trust in solving social dilemmas, we may be creating the very conditions that undermine our own democratic ways of life" (p. 18).

${ }^{3}$ The University of Zurich is the biggest university in Switzerland with overall 20,000 students and offers the whole rang of disciplines which can be studied in Switzerland.
} 
The organization of the study of economics at the University of Zurich allows us to control for different levels of economic knowledge. In a first phase the students undertake the basic study, which takes about 2 years. After passing an exam covering the basics of micro- and macroeconomics they enter the main phase and choose between political or business economics. After graduating, the students may take up their PhD study. Students can already specialize in economics in high school. We control for this pre-university knowledge (in economics). ${ }^{4}$

The strict official procedures applied when renewing student' registration offers a controlled environment while using a natural setting. The results can therefore be well compared with giving in laboratory experiments of fairness games. Moreover the amounts in question are similar to those that have been used in the experiments for analyzing the issue mentioned.

\section{Analysis and Results}

A look at the raw data seems to indicate that economists are more selfish than other students. While 60.2 percent of the economics students contribute to at least one of the funds, 67.6 percent of the students with other majors do so. In the following section the two possible explanations for this pattern of behavior will be tested: (1) selfish individuals study economics (selection hypothesis). The difference in giving behavior is therefore independent of training in economics. (2) The students adapt their behavior over time to the basic axiom of the theory they study (indoctrination hypothesis). Throughout their study economic students become more selfish according to the principles of the economic theory. Because the two explanations are not mutually exclusive it is important to discriminate between the two hypothesis.

\section{Is there a selection effect?}

To discriminate between the selection and the indoctrination hypothesis we look at the decision to contribute when first entering the university (freshmen). Differences between students of the various disciplines at the very beginning of studies (without having had any lecture in economics) supports the selection hypothesis. To account for economic knowledge

\footnotetext{
${ }^{4}$ Since a special dummy variable for students who did not pass their high school in Switzerland (therefore no information about potential pre-university knowledge in economics was available) did not prove to have an
} 
acquired at high school, a possible pre-university economics training is controlled for (preuniversity knowledge). In the appendix a description of variables is provided.

Table 1 presents the results of a probit analysis. Control variables are personal factors (age, gender, nationality), number of semesters and a dummy variables for the periods.

\section{TABLE 1}

The estimate is used to test whether the extent of giving is influenced by being subjected to economic theories. The dichotomous dependent variable equals 1 if the student contributes to at least one fund, and equals 0 if the student decides not to give any money.

The first part of Table 1 suggests that a selection effect exists. Economists in the broad sense (students can not decide between business and political economics until they reach the main phase of their studies) donate less to the fund compared to non-economists. Because in a probit analysis the coefficient is not easy to interpret, marginal effects are computed that show how the probability to contribute changes compared to the reference group. The probability that an economist contributes is more than 2 percent less than for a non-economist. To show that this lower willingness to contribute persists at the very beginning of the study the variable for economists has to be jointly interpreted with "being a very beginner" (freshmen) and with "being a freshman in economics" (freshmen*economist). The results suggest that already at the very first decision of whether to contribute (it takes place before the first lecture in economics), the economics students act more selfishly than non-economists do. ${ }^{5}$

The estimate also controls for pre-university education: having a high school education with an economics orientation significantly reduces the propensity to donate to other students. The probability to contribute is 3.7 percentage points lower. The personality variables show the following effects: All other influences being equal, the older a student is, the more likely he or she is prepared to contribute to the fund. Women and foreigners are less prepared to give. The same holds for the number of semesters a student stays at the university. This last variable suggests that repetition tends to reduce giving.

effect, it was not taken into account.

5 The overall lower probability (-6.6 percent) at the very first decision cannot be compared to first period decisions in public goods experiments, where contribution is normally highest (see e.g. Ledyard 1995). The freshmen at the University of Zurich decide before being to classes and without meeting any other students. Thus between the first and the following decisions changes an important variable which can best be describe as 'social distance'. For social distance see Bohnet and Frey (1999) and Hoffman et al. (1996). 


\section{Is there an indoctrination effect?}

If the differences in giving behavior between the students of economics and the other disciplines increases with every additional semester the indoctrination hypothesis could not be rejected. In order to capture the specific knowledge in economics we compare the behavior of the students in every stage of their studies. The reference group is constituted by noneconomists in the first phase of their studies. A move from the basic study to the main phase of the university education raises students' preparedness to help other students financially by 3.1 percentage points. In contrast, for economics students entering the main phase of studies, the probability of contributing to the fund is reduced by 8.3 percentage points. But this result cannot be interpreted as indicating the impact of indoctrination because the probability to contribute rises for doctoral students in economics by 11.1 percentage points while for doctoral students in other disciplines the willingness to donate fall by 4.2 percentage points. If indoctrination really influenced the behavior of students, the effect should be strongest at the doctoral level where the students have absorbed the largest amount of economics teaching. Thus the data do not support a negative effect of economics training on giving. This result is

further supported first by looking at two groups of economics students and second by comparing the behavior of students of economics with students in other academic disciplines. This is done in the following section. 


\section{Different behavior of students of political and business economics}

Table 2 focuses on the differences in contributing to the fund between the two types of students of the economic sciences, on the one side "political economists" and on the other side "business economists".

\section{TABLE 2}

Students are allowed to choose between the two variants of economics only in the main phase of their studies after they pass the basic study of their studies (after approximately two years). Controlling for all the factors previously also included in Table 1, political economists do not differ from all the other students. In contrast, the probability of business students to contribute to the social funds is more than 8 percent lower. This difference cannot be explained by the training in economics, first because students of political economy do not show any (statistically significant) behavioral differences to non-economics students, and, second, on a doctoral level the willingness to donate money increases for business students compared to non-economists, while political economist again do not differ significantly from the reference group.

\section{Comparison to students of other disciplines}

Table 3 compares the contribution by the students of the various disciplines again holding constant the personality and other variables previously included in Table 1.

\section{TABLE 3}

In the reference group are students in the faculty of arts which constitutes the biggest faculty at the University of Zurich (roughly 8600 students). Looking at the "pure" effect of one's chosen subject, students of the economics faculty are about as selfish as law students while a much higher share of the students of theology are prepared to subsidize other students.

When students move to the main phase of studies all are prepared to give 2.5 percentage points more but large differences between disciplines emerge. For instance, being a student of veterinary medicine lowers the probability of paying into the funds by more than 12 percentage points compared to the reference group. Business economics students give 8.5 percentage points less than art students - but this is still substantially more than veterinary students. Students of political economy give the same amount as students of the arts faculty. Our results suggest that economists are by far not the most selfish. 
When students graduate and take up their Ph.D. studies the probability that they donate money rises 3.6 percentage points. Students of medicine, of law, and of veterinary medicine give less (12.4, 9.2 and 8.6 percentage points, respectively). At the Ph.D. stage both political and business economists exhibit the same preparedness to give than students in the arts faculty. Business economists do not show less altruistic behavior at this most advanced stage of their studies.

\section{Testing for other determinants of giving behavior}

The question of whether there is an indoctrination or a self-selection effect is further studied with the help of an anonymous on-line survey among the same student population of the University of Zurich as the data set on giving behavior. ${ }^{6}$ The response rate was 25 percent, and 2,321 answers could be used. While this sample is not totally representative (not surprisingly a larger share of economics students responded to the questionnaire sent out by two economists) it is certainly not strongly biased. With respect to gender and age the sample corresponds to the distribution of students at the University of Zurich. The most important question asked was again whether a person contributes money to one or both of the funds. 73 percent responded that they did, compared to the 66 percent who actually did. Such differences between survey answers and actual behavior have also been observed with respect to voting behavior (see Matsusaka and Palda 1999). The main purpose of the survey is to better control for factors affecting giving behavior unconnected to the issue of indoctrination versus selection. The survey allows us to determine the income position, assuming that the better off a student is, the more he or she is prepared to help others. Those students working on the market to finance their studies (which is a significant part of the students at the University of Zurich) are expected to donate the less the more percentage of their living they finance by themselves. In contrast, when the parents foot the bill to study (and therefore the contribution to the funds), it is likely that the students are more generous to their fellow students. In addition, various motives for giving money to the fund were asked: its perceived necessity and effectiveness, the perceived importance of individual participation (on a scale ranging from 1 to 8 with a 'No Opinion' option; $8=$ the strongest emphasis on necessity and effectiveness of the funds, and for the importance of individual participation), one's political orientation on a left/right spectrum (ranging from 1 to $8 ; 8=$ the most left), and the expectations concerning the contribution of other students. 
Table 4 presents the probit estimates again controlling for age, gender and the number of semesters.

\section{TABLE 4}

The survey again suggests that the giving behavior of political economists does not differ significantly from non-economist but that the students of business give significantly less. The large marginal effect of doctoral students in business economics of more than $35 \%$ is a sign that there is no indoctrination effect. If it existed it would surely be the doctoral students who would be least prepared to donate. In Table 4 economists in the broad sense tend to be more inclined to contribute to the funds than non-economists do. This is due to their different values and political orientation compared to non-economist. Economists are more critical towards the funds and tend to be more on the right side of the political spectrum - both factors lower the probability of donation. Because we control in Table 4 for these variables the coefficient for economist in the broad sense gets positive. The differences in values and political orientation do not change the behavior of business economist throughout the study and exist already at the beginning of the studies and are independent of economics training. They therefore support also the selection hypothesis that business economists are a special bunch of people.

The results for the income situation and the values do not surprise. Income has the expected strong positive effect on giving. The more a student finances his own living the less he or she is willing to contribute. The fact that the parents pay the fee does not change the probability of one's own decision to donate. The variables reflecting students' values all have the expected sign and are statistically significant. The expectation regarding how many others donate money correlates positively with the decision to contribute. The variables used as controls are (with one expectation) all statistically significant and have the expected sign.

\section{Conclusions}

The analysis of the actual behavior of the students with respect to donating money to a fund as a pure public good, as well as an on-line survey of the same population, allows us to draw three conclusions:

(1) Political economists do not behave much differently from other students;

(2) It is the students of business economics who give significantly less than other students;

\footnotetext{
${ }^{6}$ The on-line questionnaire is reproduced at http://www.iew.unizh.ch/grp/frey/fragebogen.htm
} 
(3) The lower contribution of business economists compared to other students is due to selfselection rather than indoctrination.

These conclusions are based on real life behavior of students at the University of Zurich but they are likely to be of general relevance. Zurich provides a good example for a student body in a relatively large city (approximately one million inhabitants). The students of economics on which the study focuses receive a similar education in their discipline as do their counterparts elsewhere, in particular in the United States (for example, many of the textbooks used are American). As a considerable share of the students are at the same time in gainful employment, they tend to be in close contact with the rest of the population. The results reached may therefore well apply to the behavior of economists in general, i.e. outside the university setting.

The conclusions drawn are important for two quite different reasons:

- Political economists need not fear that they have a negative effect on students' behavior with respect to altruistic giving. The students, and in particular the graduates studying for a doctoral degree, well understand that political economics does not offer any normative advice with respect to giving.

- The charge often made against political economists that they produce the type of selfish homo oeconomicus they assume in their theories is unfounded.

\section{References}

Bohnet, Iris und Bruno S. Frey (1999). Social Distance and Other-Regarding Behavior in Dictator Games: Comment. American Economic Review 89, 335-339.

Bohnet, Iris und Bruno S. Frey (1995). Ist Reden Silber und Schweigen Gold? Eine ökonomische Analyse. Zeitschrift für Wirtschafts- und Sozialwissenschaften 115, 169209.

Cadsby, Charles Bram und Elizabeth Maynes (1998). Gender and Free-Riding in a Threshold Public Goods Game: Experimental Evidence. Journal of Economic Behavior and Organization 34, 603-620.

Carter, John R. und Michael D. Irons (1991). Are Economists Different, and If So, Why? Journal of Economic Perspectives 5 (2), 171-177.

Frank, Björn und Günther G. Schulze (2000). Does Economics Make Citizens Corrupt?. Journal of Economic Behavior and Organization, Forthcoming.

Frank, Robert H., Thomas Gilovich und Dennis T. Regan (1993). Does Studying Economics Inhibit Cooperation? Journal of Economic Perspectives 7 (2), 159-171.

Frank, Robert H., Thomas Gilovich und Dennis T. Regan (1996). Do Economists Make Bad Citizens? Journal of Economic Perspectives 10 (1), 187-192. 
Frey, Bruno S., Werner W. Pommerehne und Beat Gygi (1993). Economics Indoctrination or Selection? Some Empirical Results. Journal of Economic Education 24 (3), 271-281.

Hoffman, Elizabeth, Kevin McCabe und Vernon L. Smith (1996). Social Distance and OtherRegarding Behavior in Dictator Games. American Economic Review 86 (3), 653-660.

Kelman, Steven (1987). "Public Choice" and Public Spirit. The Public Interest 87 (Spring), 80-94.

Laband, David N. und Richard Beil (1999). Are Economists More Selfish Than Other 'Social' Scientists? Public Choice 100, 85-100.

Ledyard, John O. (1995). Public Goods: A Survey of Experimental Research. In: John H. Kagel und Alvin E. Roth (Hrsg.). Handbook of Experimental Economics. Princeton: Princeton University Press, 111-194.

Marwell Gerald und Ruth E. Ames (1981). Economists Free Ride, Does Anyone Else? Experiments on the Provision of Public Goods IV. Journal of Public Economics 15, 295310.

Matsusaka, John G. und Filip Palda (1999). Voter Turnout: How Much Can We Explain? Public Choice 98, 431-446.

Ostrom, Elinor (1998). A Behavioral Approach to the Rational Choice Theory of Collective Action. Presidential Address, American Political Science Association 1997. American Political Science Review 92 (1), 1-22.

Selten, Reinhard und Axel Ockenfels (1998). An Experimental Solidarity Game. Journal of Economic Behavior and Organization 34, 517-539.

Seguino, Stephanie, Thomas Stevens und Mark A. Lutz (1996). Gender and Cooperative Behavior: Economic Man Rides Alone. Feminist Economics 2 (1), 1-21.

Stanley, T.D. and Ume Tran (1998). Economics Students Need Not Be Greedy: Fairness and the Ultimatum Game. Journal of Socio-Economics 27 (6), 657-664.

Yezer, Anthony M., Robert S. Goldfarb und Paul J. Poppen (1996). Does Studying Economics Discourage Cooperation? Watch What We Do, Not What We Say or How We Play. Journal of Economic Perspectives 10 (1), 177-186. 


\section{Appendix}

Description of variables

\section{Contribution to Fund Sample}

Economic education: Dummies for economists in the broad sense, for political and for business economists, and for high school knowledge in economics. The reference group is non-economists without high school knowledge in economics.

Dummies for students of every faculty and interaction terms with the stage of study respectively. The reference group is students of the arts faculty.

Stage of study: Dummies for freshmen (students entering university), the main phase and the Ph.D. stage. The reference group is students in their basic study. Interaction terms linking the dummies for economists and the stage of study.

Demographic factors: Dummies for age between 26-30, 30-35, 36-40 and over 40, for female, and for foreigners. The reference groups is people with age under 26, male and Swiss citizen. The number of semester at the University of Zurich and the number of semester squared.

\section{Survey Sample}

Economic Education: See above.

Income situation: Log of income at one's disposal per month. Share of living costs financed by the students themselves. Dummy when the parents cover the fees going to the university. The reference group is students who pay the fee by their own.

Values: Perceived necessity and effectiveness of the funds and perceived importance of individual participation on a scale from 1 to 8 with a 'No Opinion' option; $8=$ the strongest emphasis on necessity and effectiveness of the funds, and for the importance of individual participation. Political orientation on a scale from 1 to $8 ; 8=$ the most left. Expectations about the behavior of others in percent (the question was: What do you think is the share of students who contribute to one of the funds?). 
Table 1

\section{Contribution of Economists and Non-Economists}

University of Zurich 1989-1999

Dichotomous dependent variable: 'Contribution to at least one fund' $=1$

Probit estimates

\begin{tabular}{|c|c|c|c|}
\hline Variable & coefficient & z-value & $\begin{array}{c}\text { marginal } \\
\text { effect }\end{array}$ \\
\hline Economist ( 1 = economist $)$ & $-0.070 *$ & -2.199 & $-2.5 \%$ \\
\hline \multicolumn{4}{|l|}{ Stages of study } \\
\hline Freshmen & $-0.182 * *$ & -7.454 & $-6.6 \%$ \\
\hline Freshmen*Economist & 0.017 & 0.257 & $0.6 \%$ \\
\hline Main phase & $0.084 * *$ & 5.411 & $3.1 \%$ \\
\hline Main phase*Economist & $-0.229 * *$ & -5.656 & $-8.3 \%$ \\
\hline Ph.D. & $-0.115 * *$ & -6.633 & $-4.2 \%$ \\
\hline Ph.D.*Economist & $0.306^{* *}$ & 5.080 & $11.1 \%$ \\
\hline Pre-university knowledge & $-0.103 * *$ & -7.037 & $-3.7 \%$ \\
\hline \multicolumn{4}{|l|}{ Control variables } \\
\hline Age 26-30 & -0.009 & -0.573 & $-0.3 \%$ \\
\hline Age $31-35$ & $0.187 * *$ & 8.596 & $6.8 \%$ \\
\hline Age $36-40$ & $0.341 * *$ & 11.755 & $12.3 \%$ \\
\hline Age over 40 & $0.517 * *$ & 16.424 & $18.7 \%$ \\
\hline Gender $($ female $=1)$ & $-0.030 * *$ & -2.657 & $-1.1 \%$ \\
\hline Nationality (foreigner=1) & $-0.077 * *$ & -4.431 & $-2.8 \%$ \\
\hline Number of semester & $-0.045 * *$ & -17.515 & $-1.6 \%$ \\
\hline${\text { (Number of semester })^{2}}^{2}$ & $0.001 * *$ & 10.379 & $0.02 \%$ \\
\hline Period 2 (summer term 1999) & $0.071 * *$ & 10.014 & $2.6 \%$ \\
\hline Period 3 (winter term 99/00) & $0.139 * *$ & 10.510 & $5.0 \%$ \\
\hline Constant & $0.690 * *$ & 34.518 & \\
\hline $\mathrm{N}$ & 57,510 & & \\
\hline Log Likelihood & -35809.65 & & \\
\hline Pseudo $\mathrm{R}^{2}$ & 0.020 & & \\
\hline
\end{tabular}

Notes: Reference group is 'non-economists', 'basic study', 'without pre-university economic knowledge', 'age under 26', 'male', 'Swiss', 'semester 1998/99'.

Level of significance: $* 0.01<\mathrm{p}<0.05, * * \mathrm{p}<0.01$

Source: Compiled on the data provided by the department of accounting of the University of Zurich. 
Table 2

\section{Contribution of Political and Business Economists}

University of Zurich 1989-1999

Dichotomous dependent variable: 'Contribution to at least one fund' $=1$

Probit estimates

\begin{tabular}{|c|c|c|c|}
\hline Variable & coefficient & z-value & $\begin{array}{c}\text { marginal } \\
\text { effect }\end{array}$ \\
\hline Economist (in the broad sense) & $-0.106 * *$ & -3.821 & $-3.9 \%$ \\
\hline \multicolumn{4}{|l|}{ Stages of study } \\
\hline Freshmen & $-0.184 * *$ & -7.537 & $-6.7 \%$ \\
\hline Freshmen*Economist & 0.049 & 0.77 & $1.8 \%$ \\
\hline Main phase & $0.075^{* *}$ & 4.919 & $2.7 \%$ \\
\hline Main phase*Political Economist & 0.003 & 0.035 & $0.1 \%$ \\
\hline Main phase*Business Economist & $-0.226 * *$ & -5.652 & $-8.2 \%$ \\
\hline Ph.D. & $-0.111 * *$ & -6.415 & $-4.0 \%$ \\
\hline Ph.D.*Political Economist & 0.168 & 1.315 & $6.1 \%$ \\
\hline Ph.D.*Business Economist & $0.294 * *$ & 4.028 & $10.6 \%$ \\
\hline Pre-university economic knowledge & $-0.103 * *$ & -7.071 & $-3.8 \%$ \\
\hline \multicolumn{4}{|l|}{ Control variables } \\
\hline Age $26-30$ & -0.008 & -0.485 & $-0.3 \%$ \\
\hline Age $31-35$ & $0.188 * *$ & 8.633 & $6.8 \%$ \\
\hline Age $36-40$ & $0.341 * *$ & 11.760 & $12.3 \%$ \\
\hline Age over 40 & $0.518 * *$ & 16.442 & $18.7 \%$ \\
\hline Gender $($ female $=1)$ & $-0.029 * *$ & -2.578 & $-1.0 \%$ \\
\hline Nationality (foreigner $=1$ ) & $-0.076 * *$ & -4.398 & $-2.8 \%$ \\
\hline Numbers of semester & $-0.045 * *$ & -17.515 & $-1.6 \%$ \\
\hline$(\text { Number of semester })^{2}$ & $0.001 * *$ & 10.388 & $0 \%$ \\
\hline Period 2 (summer term 1999) & $0.072 * *$ & 5.285 & $2.6 \%$ \\
\hline Period 3 (winter term 1999/00) & $0.142 * *$ & 10.711 & $5.1 \%$ \\
\hline Constant & $0.695 * *$ & 34.956 & \\
\hline $\mathrm{N}$ & 57,510 & & \\
\hline Log Likelihood & -35883.329 & & \\
\hline Pseudo $\mathrm{R}^{2}$ & 0.0181 & & \\
\hline
\end{tabular}

Notes: Reference group is 'non-economists', 'basic study', 'without pre-university economic knowledge', 'age under 26', 'male', 'Swiss', 'semester 1998/99'.

Level of significance: $* 0.01<\mathrm{p}<0.05, * * \mathrm{p}<0.01$

Source: Compiled on the data provided by the department of accounting of the University of Zurich. 
Table 3

\section{Contribution of Economists and Students of Other Faculties}

University of Zurich 1989-1999

Dichotomous dependent variable: 'Contribution to at least one funds' $=1$, Probit estimates

\begin{tabular}{|c|c|c|c|}
\hline Variable & coefficient & z-value & Marginal effect \\
\hline Economics & $-0.177 * *$ & -5.163 & $-6.4 \%$ \\
\hline Theology & $0.235^{*}$ & 2.521 & $8.5 \%$ \\
\hline Law & $-0.182 * *$ & -5.011 & $-6.6 \%$ \\
\hline Medicine & 0.041 & 1.012 & $1.5 \%$ \\
\hline Veterinary medicine & -0.070 & -1.158 & $-2.5 \%$ \\
\hline Natural science & -0.038 & -0.915 & $-1.4 \%$ \\
\hline Informatic & -0.054 & -0.997 & $-2.0 \%$ \\
\hline Main phase* & $0.068 *$ & 2.197 & $2.5 \%$ \\
\hline Political economics & -0.002 & -0.021 & $-0.1 \%$ \\
\hline Business economics & $-0.234 * *$ & -5.272 & $-8.5 \%$ \\
\hline Theology & 0.015 & 0.107 & $0.5 \%$ \\
\hline Law & -0.062 & -1.468 & $-2.2 \%$ \\
\hline Medicine & $-0.130 *$ & -2.545 & $-4.7 \%$ \\
\hline Veterinary medicine & $-0.350 * *$ & -3.99 & $-12.6 \%$ \\
\hline Natural science & $-0.139 * *$ & -2.791 & $-5.0 \%$ \\
\hline Computer Science & -0.158 & -1.948 & $-5.7 \%$ \\
\hline Ph.D.* & $0.099 * *$ & 3.481 & $3.6 \%$ \\
\hline Political economics & -0.026 & -0.199 & $-0.9 \%$ \\
\hline Business economics & 0.087 & 1.136 & $3.1 \%$ \\
\hline Law & $-0.256 * *$ & -5.245 & $-9.2 \%$ \\
\hline Theology & -0.282 & -1.815 & $-10.2 \%$ \\
\hline Medicine & $-0.342 * *$ & -7.103 & $-12.4 \%$ \\
\hline Veterinary medicine & $-0.239 * *$ & -2.706 & $-8.6 \%$ \\
\hline Computer Science & 0.013 & 0.264 & $0.5 \%$ \\
\hline Natural science & -0.195 & -1.571 & $-7.0 \%$ \\
\hline Pre-university economic knowledge & $-0.076 * *$ & -5.135 & $-2.8 \%$ \\
\hline $\mathrm{N}$ & 57,510 & & \\
\hline Log Likelihood & -35590.254 & & \\
\hline Pseudo $\mathrm{R}^{2}$ & 0.0261 & & \\
\hline
\end{tabular}

Notes: Reference group is 'students of the arts faculty', 'basic study', 'without pre-university economic knowledge', 'age under 26', 'male', 'Swiss', 'semester 1998/99'. Due to lack of space the control variable of table 1 are not shown in the table.

$*$ the variables below are interaction terms.

Level of significance: $* 0.01<\mathrm{p}<0.05, * * \mathrm{p}<0.01$

Source: Compiled on the data provided by the department of accounting of the University of Zurich. 
Table 4

\section{Factors Affecting the Giving Behavior}

University of Zurich 2000

Dichotomous dependent variable: 'Contribution to at least one fund' $=1$

Probit estimates

\begin{tabular}{|c|c|c|c|}
\hline Variable & Coefficient & z-value & $\begin{array}{c}\text { marginal } \\
\text { effect }\end{array}$ \\
\hline Economist (in the broad sense) & $0.391 * *$ & 2.829 & $11.3 \%$ \\
\hline \multicolumn{4}{|l|}{ Stages of study } \\
\hline Main phase & 0.080 & 0.944 & $2.3 \%$ \\
\hline Main phase*Political Economist & -0.208 & -0.648 & $-6.0 \%$ \\
\hline Main phase*Business Economist & $-0.413 *$ & -2.087 & $-12.0 \%$ \\
\hline Ph.D. & 0.119 & 0.947 & $3.5 \%$ \\
\hline Ph.D.*Political Economist & 0.156 & 0.261 & $4.5 \%$ \\
\hline Ph.D.*Business Economist & 1.234 & 1.614 & $35.7 \%$ \\
\hline \multicolumn{4}{|l|}{ Income situation } \\
\hline Log (income) & $0.188 * *$ & 3.88 & $5.5 \%$ \\
\hline Percent of own living & $-0.003 *$ & -2.249 & $-0.1 \%$ \\
\hline Parents pay fees & 0.067 & 0.785 & $2.0 \%$ \\
\hline \multicolumn{4}{|l|}{ Values } \\
\hline Importance to contribute & $0.241 * *$ & 10.963 & $7.0 \%$ \\
\hline Necessity of funds & $0.095 * *$ & 3.49 & $2.7 \%$ \\
\hline Effectiveness of funds & $0.085 * *$ & 3.235 & $2.5 \%$ \\
\hline No opinion 'importance' & $0.851 * *$ & 4.84 & $24.6 \%$ \\
\hline No opinion 'necessity' & $0.367^{(*)}$ & 1.893 & $10.6 \%$ \\
\hline No opinion 'effectiveness' & $0.479 * *$ & 3.065 & $13.9 \%$ \\
\hline Political orientation & $0.060 * *$ & 2.617 & $1.8 \%$ \\
\hline $\begin{array}{l}\text { Expectation about behavior } 0 \\
\text { others }\end{array}$ & f $0.019 * *$ & 11.327 & $0.6 \%$ \\
\hline \multicolumn{4}{|l|}{ Control variables } \\
\hline Age & $0.016^{(*)}$ & 1.917 & $0.5 \%$ \\
\hline Sex $($ female=1) & $-0.180 * *$ & -2.627 & $-5.2 \%$ \\
\hline Number of semester & $-0.019 *$ & -2.505 & $-0.6 \%$ \\
\hline Constant & $-4.780 * *$ & -11.393 & \\
\hline $\mathrm{N}$ & 2,321 & & \\
\hline Log likelihood & -979.11015 & & \\
\hline $\mathrm{R} 2$ & 0.2653 & & \\
\hline
\end{tabular}

Notes: Reference group is 'non-economists', 'basic study', 'male', who 'pay the fee by themselves'.

Level of significance: $\left.{ }^{*}\right) 0.05<\mathrm{p}<0.1, * 0.01<\mathrm{p}<0.05$, ** $\mathrm{p}<0.01$

Source: Own survey at the University of Zurich. 


\section{Working Papers of the Institute for Empirical Research in Economics}

No.

1. Rudolf Winter-Ebmer and Josef Zweimüller: Firm Size Wage Differentials in Switzerland: Evidence from Job Changers, February 1999

2. Bruno S. Frey and Marcel Kucher: History as Reflected in Capital Markets: The Case of World War II, February 1999

3. Josef Falkinger, Ernst Fehr, Simon Gächter and Rudolf Winter-Ebmer: A Simple Mechanism for the Efficient Provision of Public Goods - Experimental Evidence, February 1999

4. Ernst Fehr and Klaus M. Schmidt: A Theory of Fairness, Competition and Cooperation, April 1999

5. Markus Knell: Social Comparisons, Inequality, and Growth, April 1999

6. Armin Falk and Urs Fischbacher: A Theory of Reciprocity, July 2000

7. Bruno S. Frey and Lorenz Goette: Does Pay Motivate Volunteers?, May 1999

8. Rudolf Winter-Ebmer and Josef Zweimüller: Intra-firm Wage Dispersion and Firm Performance, May 1999

9. Josef Zweimüller: Schumpeterian Entrepreneurs Meet Engel's Law: The Impact of Inequality on InnovationDriven Growth, May 1999

10. Ernst Fehr and Simon Gächter: Cooperation and Punishment in Public Goods Experiments, June 1999

11. Rudolf Winter-Ebmer and Josef Zweimüller: Do Immigrants Displace Young Native Workers: The Austrian Experience, June 1999

12. Ernst Fehr and Jean-Robert Tyran: Does Money Illusion Matter?, June 1999

13. Stefan Felder and Reto Schleiniger: Environmental Tax Reform: Efficiency and Political Feasibility, July 1999

14. Bruno S. Frey: Art Fakes - What Fakes?, An Economic View, July 1999

15. Bruno S. Frey and Alois Stutzer: Happiness, Economy and Institutions, July 1999

16. Urs Fischbacher, Simon Gächter and Ernst Fehr: Are People Conditionally Cooperative? Evidence from a Public Goods Experiment, July 2000

17. Armin Falk, Ernst Fehr and Urs Fischbacher: On the Nature of Fair Behavior, August 1999

18. Vital Anderhub, Simon Gächter and Manfred Königstein: Efficient Contracting and Fair Play in a Simple Principal-Agent Experiment, September 2000

19. Simon Gächter and Armin Falk: Reputation or Reciprocity?, September 1999

20. Ernst Fehr and Klaus M. Schmidt: Fairness, Incentives, and Contractual Choices, September 1999

21. Urs Fischbacher: $z$-Tree - Experimenter's Manual, September 1999

22. Bruno S. Frey and Alois Stutzer: Maximising Happiness?, October 1999

23. Alois Stutzer: Demokratieindizes für die Kantone der Schweiz, October 1999

24. Bruno S. Frey: Was bewirkt die Volkswirtschaftslehre?, October 1999

25. Bruno S. Frey, Marcel Kucher and Alois Stutzer: Outcome, Process \& Power in Direct Democracy, November 1999

26. Bruno S. Frey and Reto Jegen: Motivation Crowding Theory: A Survey of Empirical Evidence, November 1999

27. Margit Osterloh and Bruno S. Frey: Motivation, Knowledge Transfer, and Organizational Forms, November 1999

28. Bruno S. Frey and Marcel Kucher: Managerial Power and Compensation, December 1999

29. Reto Schleiniger: Ecological Tax Reform with Exemptions for the Export Sector in a two Sector two Factor Model, December 1999

30. Jens-Ulrich Peter and Klaus Reiner Schenk-Hoppé: Business Cycle Phenomena in Overlapping Generations Economies with Stochastic Production, December 1999

31. Josef Zweimüller: Inequality, Redistribution, and Economic Growth, January 2000

32. Marc Oliver Bettzüge and Thorsten Hens: Financial Innovation, Communication and the Theory of the Firm, January 2000

33. Klaus Reiner Schenk-Hoppé: Is there a Golden Rule for the Stochastic Solow Growth Model? January 2000

34. Ernst Fehr and Simon Gächter: Do Incentive Contracts Crowd out Voluntary Cooperation? February 2000

35. Marc Oliver Bettzüge and Thorsten Hens: An Evolutionary Approach to Financial Innovation, July 2000

36. Bruno S. Frey: Does Economics Have an Effect? Towards an Economics of Economics, February 2000

37. Josef Zweimüller and Rudolf Winter-Ebmer: Firm-Specific Training: Consequences for Job-Mobility, March 2000

The Working Papers of the Institute for Empirical Research in Economics can be downloaded in PDF-format from http://www.unizh.ch/iew/wp/ 


\section{Working Papers of the Institute for Empirical Research in Economics}

No.

38. Martin Brown, Armin Falk and Ernst Fehr: Contract Inforcement and the Evolution of Longrun Relations, March 2000

39. Thorsten Hens, Jörg Laitenberger and Andreas Löffler: On Uniqueness of Equilibria in the CAPM, July 2000

40. Ernst Fehr and Simon Gächter: Fairness and Retaliation: The Economics of Reciprocity, March 2000

41. Rafael Lalive, Jan C. van Ours and Josef Zweimüller: The Impact of Active Labor Market Programs and Benefit Entitlement Rules on the Duration of Unemployment, March 2000

42. Reto Schleiniger: Consumption Taxes and International Competitiveness in a Keynesian World, April 2000

43. Ernst Fehr and Peter K. Zych: Intertemporal Choice under Habit Formation, May 2000

44. Ernst Fehr and Lorenz Goette: Robustness and Real Consequences of Nominal Wage Rigidity, May 2000

45. Ernst Fehr and Jean-Robert Tyran: Does Money Illusion Matter? REVISED VERSION, May 2000

46. Klaus Reiner Schenk-Hoppé: Sample-Path Stability of Non-Stationary Dynamic Economic Systems, Juni 2000

47. Bruno S. Frey: A Utopia? Government without Territorial Monopoly, June 2000

48. Bruno S. Frey: The Rise and Fall of Festivals, June 2000

49. Bruno S. Frey and Reto Jegen: Motivation Crowding Theory: A Survey of Empirical Evidence, REVISED VERSION, June 2000

50. Albrecht Ritschl and Ulrich Woitek: Did Monetary Forces Cause the Great Depression? A Bayesian VAR Analysis for the U.S. Economy, July 2000

51. Alois Stutzer and Rafael Lalive: The Role of Social Work Norms in Job Searching and Subjective Well-Being, July 2000

52. Iris Bohnet, Bruno S. Frey and Steffen Huck: More Order with Less Law: On Contract Enforcement, Trust, and Crowding, July 2000

53. Armin Falk and Markus Knell: Choosing the Joneses: On the Endogeneity of Reference Groups, July 2000

54. Klaus Reiner Schenk-Hoppé: Economic Growth and Business Cycles: A Critical Comment on Detrending Time Series, August 2000

55. Armin Falk, Ernst Fehr and Urs Fischbacher: Appropriating the Commons - A Theoretical Explanation, September 2000

56. Bruno S. Frey and Reiner Eichenberger: A Proposal for a Flexible Europe, August 2000

57. Reiner Eichenberger and Bruno S. Frey: Europe's Eminent Economists: A Quantitative Analysis, September 2000

58. Bruno S. Frey: Why Economists Disregard Economic Methodology, September 2000

59. Armin Falk, Ernst Fehr, Urs Fischbacher: Informal Sanctions, September 2000

60. Rafael Lalive: Did we Overestimate the Value of Health?, October 2000

61. Matthias Benz, Marcel Kucher and Alois Stutzer: Stock Options: the Managers' Blessing. Institutional Restrictions and Executive Compensation, October 2000

62. Simon Gächter and Armin Falk: Work motivation, institutions, and performance, October 2000

63. Armin Falk, Ernst Fehr and Urs Fischbacher: Testing Theories of Fairness - Intentions Matter, September 2000

64. Ernst Fehr and Klaus Schmidt: Endogenous Incomplete Contracts, November 2000

65. Klaus Reiner Schenk-Hoppé and Björn Schmalfuss: Random fixed points in a stochastic Solow growth model, November 2000

66. Leonard J. Mirman and Klaus Reiner Schenk-Hoppé: Financial Markets and Stochastic Growth, November 2000

67. Klaus Reiner Schenk-Hoppé: Random Dynamical Systems in Economics, December 2000

68. Albrecht Ritschl: Deficit Spending in the Nazi Recovery, 1933-1938: A Critical Reassessment, December 2000

69. Bruno S. Frey and Stephan Meier: Political Economists are Neither Selfish nor Indoctrinated, December 2000

The Working Papers of the Institute for Empirical Research in Economics can be downloaded in PDF-format from http://www.unizh.ch/iew/wp/

Institute for Empirical Research in Economics, Blümlisalpstr. 10, 8006 Zürich, Switzerland

Phone: 004116343705 Fax: 004116344907 E-mail: bibiewzh@iew.unizh.ch 